\title{
DESPRE UN MORMÂNT DESCOPERIT LA PECICA-HĂBLĂU (MĂNĂSTIREA LUI AHTUM), JUDEȚUL ARAD ${ }^{1}$
}

\section{Silviu OŢA, ALEXANDRA COMŞA}

\section{ABOUT A GRAVE DISCOVERED IN PECICA-HĂBLĂU (MONASTERY OF AHTUM) (ARAD COUNTY)}

The archaeological site Pecica-Monastery of Ahtum is located in Arad County, at the point called Hăblău, on the Mureş River (PI. I). The monastery is known in the medieval documents dating from the fourteenth century. The archaeological research on site indicated the existence of two churches, partially overlapping. The authors of the research also assumed the existence of an older church which however was completely destroyed, dated to the late tenth century or the beginning of the following one. One of their arguments was the discovery of a grave (G. 1) whose inventory consisted of a belt with appliqués (PI. II-V; Pl. VI/3-8, 10), thought of as belonging to the tenth-eleventh centuries. The items and several bones of the skeleton were delivered to the National Museum of Romanian History for investigations and restoration. After cleaning the material, I tried to corroborate the information published on the grave with the newly discovered items after washing the osteological remains, as it appeared that there were new elements remained unknown. This is added by the fact that some of the artefacts were not mentioned in any excavation report.

CUVINTE CHEIE: mormânt, aplice, centură, mănăstire, foiță de bronz, oase, vertebre KEYWORDS: grave, appliqués, belt, monastery, bronze foil, bones, vertebrae

\section{INTRODUCERE}

Şantierul arheologic Pecica-Mănăstirea lui Ahtum se află în județul Arad, în punctul numit Hăblău, pe malul râului Mureș (PI. I). Acesta a fost cercetat parțial în anii '90 de către Szuzana și Radu Heitel $^{2}$. Mănăstirea este cunoscută în documentele medievale din veacul al XIV-lea ${ }^{3}$. Conform autorilor cercetării, numele său indică însă că trebuie să fi avut o vechime cu mult mai mare, începuturile sale putând fi căutate la sfârșitul secolului al X-lea sau începutul celui următor. Cel mai probabil, locul aparținea lui Ahtum sau a descendenților săi.

Cercetările arheologice de aici au demonstrat existența a două monumente de cult, parţial suprapuse. O primă biserică identificată a fost datată cel mai probabil în cursul secolului al XII-lea sau eventual la începutul celui următor (din păcate rapoartele de săpătură sunt destul de neclare şi contradictorii). Cea de-a doua, care o suprapunea pe aceasta, a fost datată în a doua jumătate a secolului al XIII-lea. Distrugerea mănăstirii a fost plasată în cursul secolului al XVI-lea.

Autorii cercetării au presupus şi existenţa unei biserici mai vechi, aceasta fiind însă complet distrusă, datată la sfârşitul secolului al X-lea sau începutul celui următor. Unul din argumentele cercetătorilor a fost descoperirea unui mormânt (M.1) care avea ca inventar o centură cu aplice, considerată ca aparținând secolelor $\mathrm{X}-\mathrm{XI}^{4}$. Din păcate, nu a fost publicat un profil cu stratigrafia secțiunii în zona M.1.

\footnotetext{
${ }^{1}$ Articolul a mai fost publicat în limba engleză în revista GSAD 31/2015 la p. 143-164 cu titlul On a Grave Discovered in Pecica - Hăblău (Monastery of Ahtum) (Arad County). Versiunea în limba română cuprinde câteva mici completări (note, bibliografie și precizări suplimentare).

${ }^{2}$ Heitel 2010, 63.

${ }^{3}$ DIR XIV, C., II, 290-291; Suciu 1968, 280; Györffy 1963, 846; Heitel 2010, 63, nota 3.

${ }^{4}$ Din păcate, nu au oferit vreo analogie în acest sens.
} 
Piesele şi câteva oase din schelet au fost aduse la MNIR pentru investigații și restaurare ${ }^{5}$. Piesele au rămas necurăţate, aşa cum au fost predate. Fiind confecţionate din foiţe de metal, foarte subţiri, multe s-au dezintegrat.

În urma curăţării materialului, am încercat să coroborez informaţia publicată asupra mormântului ${ }^{6}$ cu piesele nou descoperite după spălarea resturilor osteologice, deoarece păreau că sunt elemente noi rămase necunoscute. Se adaugă şi faptul că o parte a artefactelor nu au fost menţionate în nici un raport de săpătură.

\section{INFORMAȚIA CONFORM RAPORTULUI DE CERCETARE}

Mormântul în cauză, anume nr. 1/1994, a fost descoperit în S. III/1994, în carourile 4-6, între metrii 3,50 şi 5,40, la o dâncime de 2,40 m. Defunctul a fost depus în sicriu de lemn cu un capac (PI. VIII/4, 4a, 5, 5a, 6, 6a, 7, 7a, 8, 8a) ${ }^{7}$. Deasupra sa, spre mijloc au fost descoperite oase de la un animal mic ${ }^{8}$. Mormântul avea orientarea V-E. Lungimea scheletului era de $1,52 \mathrm{~m}$ şi s-a apreciat că trebuie să fi aparţinut unei persoane de sex feminin. Defunctul a fost depus în poziţia decubit dorsal, cu antebraţul drept peste cel stâng, deasupra bazinului. Laba piciorului drept a fost la o distanţă de 8 $\mathrm{cm}$ de talpa de fundație a zidului de vest al bisericii, la exterior.

Conform descrierii, ca inventar avea o centură (PI. VII/1-5; PI. XI/2-4, 6) decorată cu ,,aplice cu decor floral" (diam.=1,5 cm), fixate cu nituri având capetele cu decor floral sau simple $(\mathbf{P I}$. XI/8). Centura „lată de 10 cm,” (!?) avea o limbă de curea şi o cataramă (PI. II/5; PI. XI/1). Deasupra femurului stâng era o piesă tubulară (PI. VIII/3), ,lungă de 14 cm”, în poziţie verticală, ,cu diametrul de $1,5 \mathrm{~cm}$ ". Spre centură, tubul de fier intra sub o placă dispusă perpendicular pe el, care avea „lungimea de $10 \mathrm{~cm}$ şi lăţimea de $2 \mathrm{~cm}$.” Această placă era decorată cu aceleaşi aplice florale şi „,părea atârnată de centură". În zona centurii, a bazinului şi de-a lungul femurului stâng, dar şi în zona sternului avea nituri simple sau cu capete florale (PI. III/7; PI. IV/1; PI. V/1, 6, 10, 11, 16-19, 20; PI. VI/2, 2a, 9). Tot autorul menționează că în diverse puncte ale mormântului erau bile metalice ${ }^{9}$ (Pl. VIII/1) şi mici piese tubulare corodate (Pl. VIII/2) puternic. De asemenea, în mormânt erau şi bucăţi de mortar, provenite de la construcţia, probabil, a unei biserici mai vechi, anterioare (PI. VII/6-7), databilă în jurul anului 1000, probabil suprapusă de cea găsită acolo, ridicată în secolul al XIII-lea.

Elementele noi privind inventarul funerar sunt esenţiale în redatarea mormântului. La o reinventariere a materialelor găsite în MNIR, şi o analiză mai atentă a modului de confecţionare a accesoriilor vestimentare, am descoperit pe lângă piesele publicate cu fotografie, câteva aplice care pot schimba cronologia mormântului.

În primul rând, după curățarea oaselor și o privire mai atentă a pieselor aduse, am descoperit şase tipuri de aplice, o limbă de curea și nituri care aveau capul în formă de floare ${ }^{10}$.

1. APLICE TIP FlOARE am distins aproximativ 27 exemplare $(16 / 15,5 \mathrm{~mm}$, grosimea $=0,3 \mathrm{~mm}$; Pl. II/4, 6; Pl. III/2-6, 9-15; Pl. IV/2; Pl. V/2, 3, 5, 7, 12, 15; Pl. VI/10).

2. APLICE ALUNGITE. Nu li se poate preciza numărul, dar probabil că sunt în număr destul de mare $(1=$ $4 \mathrm{~mm}$, grosimea = 1,6 mm; Pl. III/16-19; PI. V/4, 8, 9, 13, 14; PI. VI/3, 3a, 4, 4a, 5, 5a, 6, 6a, 7, 7a, 8, 8a; Pl. XI/7).

\footnotetext{
${ }^{5}$ Piesele, după decesul autorilor cercetării, au fost uitate în sectorul Restaurare Metale până în anul 2012. Deoarece autorii cercetării nu mai sunt în viaţă şi nimeni nu a revendicat materialul în cauză, am solicitat direcţiei MNIR şi domnului Crişan Muşeţeanu, cel care adusese materialul în discuție în muzeu, preluarea sa pentru un studiu mai amănunți şi permisiunea de a valorifica științific aceste piese. Au fost realizate fotografii, radiografii şi analize ale pieselor de metal descoperite.

${ }^{6}$ Heitel 2010, 67-68.

${ }^{7} \mathrm{~S}$-au mai păstrat trei fragmente de cuie de fier (PI. VIII/4, 4a, 5, 5a, 6, 6a, 7, 7a, 8, 8a).

${ }^{8}$ Autorii cercetării au considerat că probabil aparțin unei pisici (Heitel 2010, 67).

${ }^{9}$ În realitate era doar o jumătate de sferă din fier.

${ }^{10}$ Acestea din păcate sunt distruse şi nu pot fi restaurate.
} 
3. APLiCE TRIUNGHIULARE. S-au păstrat două fragmente și sunt de mici dimensiuni, cu un vârf, probabil rotunjit. Cel mai bine păstrat fragment are dimensiunea de 10/10 mm (PI. III/20-21).

4. APLICĂ RECTANGULARĂ, ruptă în două, cu o perforație centrală. S-a păstrat doar un exemplar (L = $21,5 \mathrm{~mm}, 1=16 \mathrm{~mm}$, grosimea $=0,4 \mathrm{~mm} ; \mathbf{P l}$. III/1, 8; Pl. XI/5a-b) ${ }^{11}$.

5. Aplică ReCtangUlară, cu patru nituri $(\mathrm{L}=22,2 \mathrm{~mm}, 1=15 \mathrm{~mm}$, grosimea $=0,5 \mathrm{~mm} ; \mathbf{P l} . \mathbf{I I} / \mathbf{2} ; \mathbf{P l}$. $\mathrm{XI} / \mathbf{9})$.

6. APLICĂ TRAPEZOIDALĂ, cu perforație centrală, avea probabil nituri la colţuri $(\mathrm{L}=33 \mathrm{~mm}, 1=20$ $\mathrm{mm}$, grosimea $=0,4 \mathrm{~mm}$ ). Piesa este ruptă în mare parte, dar din ce s-a mai păstrat, conform radiografiei are decor în ghirlande duble, aplicat pe o latură, executat prin punctare. Se prindea de centură prin nituri, dar s-a mai păstrat un singur orificiu pentru acestea (PI. II/3; PI. IX/1-2; PI. $\mathbf{X I} / \mathbf{1 1})$.

7. ApliCă ReCTANGUlaRĂ, cu o tăietură de aceeași formă pe centru $(H=16,6 \mathrm{~mm}, \mathrm{~L}=14,4 \mathrm{~mm}$ păstrat). La colţurile păstrate are două nituri de care era prins un alt rest de placă $(\mathbf{P I}$. II/1; PI. XI/10).

Lungime adunată a pieselor recuperate ajunge la aproximativ $55 \mathrm{~cm}$, fără limba de curea atârnată. Dacă avem în vedere şi spaţiile necesare dintre aplice, am putea dubla lungimea acestei centuri. Din păcate nu putem spune mare lucru despre ordinea aplicelor. Dacă avem în vedere piesa de la Petrovcsics, lângă cataramă trebuie să fi fost măcar o plăcuţă de bronz ${ }^{12}$, dar aici avem trei astfel de piese. Lângă ele, urmau aplicele alungite, dispuse vertical, paralele.

Dintre acestea, cel mai important element îl constituie aplicele nr. 2, necunoscute autorilor cercetării. Acestea sunt identice cu cele descoperite în M.1. de la Petrovcsics, din regiunea Sirmium ${ }^{13}$.

Un al doilea element important îl constituie faptul că modul de execuție al aplicelor florale (nr. 1), aproape identice cu un exemplar descoperit pe placa de la catarama centurii din aceeași localitate, este realizat oarecum atipic pentru piesele din Pannonia secolului al X-lea. Acestea erau în cea mai mare parte piese din argint sau bronz, turnate cu tot cu nituri ${ }^{14}$. Doar foarte rar sunt din foiţă de bronz sau argint. Exemplarele de la Pecica au fost executate din foiţă de bronz, acoperită la suprafață cu staniu pentru a crea senzația că sunt din argint, conform analizelor chimice ${ }^{15}$. Acest procedeu a fost posibil ca urmare a temperaturilor de topire a celor două metale care sunt diferite ( $\mathrm{Sn}$ se topește la $231^{\circ} \mathrm{C}$ bronzul la $880-1040^{\circ} \mathrm{C}$ ). Al doilea element îl constituie faptul că niturile sunt fixate după confecționarea aplicelor. Modelul decorativ, deși poate părea asemănător cu piesele din veacul al Xlea, în acest moment nu are analogii decât la Petrovcsics.

Un alt element similar cu piesele din Serbia, îl constituie catarama, identică din punct de vedere al formei ${ }^{16}$. Ei i se mai adaugă faptul că decorul unei plăci de centură a fost parțial executat prin punctare, anume două rânduri, asemeni piesei din Serbia. Diferența constă în faptul că piesa de la Pecica este decorată cu ghirlande, nu cu linii drepte punctate (PI. IX).

O altă inadvertență, constă în faptul că o mare parte a niturilor cu cap floral nu se dovedesc a fi altceva decât fragmente de aplice florale sau alungite, distruse sau care, prin corodare s-au dezintegrat. Datorită corodării lor, nu se mai pot distinge foarte bine care au aparținut aplicelor şi care sunt cele care au cap floral. Ceea ce se poate spune este doar faptul că sunt de mai multe feluri, dovadă că ele aparțin unor piese sau aplice diferite. Sunt astfel, nituri cu lungimea de 4,5 $\mathrm{mm}$ şi diametrul de

\footnotetext{
${ }^{11}$ Dumitriu 2001, 131, Taf. 44/60, 61; Reabţeva 2014, 335, Fig. 93/14.

12 Dacă în fotografia publicată în anul 2000 ordinea pieselor este fie şi parţial cea descoperită în mormânt, atunci după cataramă urma aplica.

${ }^{13}$ Stanojev 1989, 91, 93/fig. 495-501; Jovanović 1977, 155.

${ }^{14}$ Pletnjov, Pavlova 1994-1995, 24-239.

15 Pentru identificarea relativă a compoziției pieselor, care păreau a fi din argint sau care aveau oxizi de cupru pe suprafața lor, au fost efectuate de către inginer Migdonia Georgescu (Centrul Naţional de Cercetări şi Investigaţii Fizico-Chimice şi Biologice - MNIR) măsurători prin fluorescenţă de raze X, cu ajutorul unui spectrometru portabil tip InnovX Alpha Series, prevăzut cu anticatod din W, detector SiPIN cu răcire prin efect Peltier, tensiunea aplicată $30 \mathrm{kV}$, intensitatea 40 micro A şi un timp de achiziție de $30 \mathrm{~s}$. Mulțumirile autorului doamnei Migdonia Georgescu.

${ }^{16} \mathrm{O}$ piesă similară a mai fost descoperită şi în Croația, la Torček-Cirkvišče, în M. 243, iar datarea sa este similară, anume sfârşitul secolului al XIII-lea şi începutul celui de-al XIV-lea (Krznar 2015, 56, 57, sl. 9). Mulțumim pentru precizări domnului Siniša Krznar. Alte piese asemănătoare, considerate ca fiind catarame în forma literei $\mathrm{D}$, au fost publicate şi de către R. Whitehead (Whitehead 1996, 19, nr. cat. 51-54, 56). Acestea au avut o circulație în timp destul de lungă, de după mijlocul secolului al XIII-lea până spre 1500.
} 
1,5 mm. Alte nituri, au lungimea de 3,7 mm şi diametrul de $0,9 \mathrm{~mm}$ (are şi bucăți de aplică). Altele au 5,1 mm şi diametrul de 1,6-1,7 mm (acestea au şi bucăţi din aplică). Şi în acest caz, elucidarea vine tot de la inventarul unui alt mormânt, anume M.2 din aceeași localitate Petrovesics ${ }^{17}$. De o parte şi de alta a sternului, acesta avea două rânduri de nituri cu cap floral. În lipsa unui plan al mormântului de la Pecica, rămâne doar să presupunem că şi M.1 de aici avea acelaşi tip de piese, dispuse similar cu cele din M.2 de la Petrovcsics.

În afara acestor piese cunoscute, am mai găsit resturi de împletituri de sfoară (PI. VI/1; PI. XI/12a-c) combinată cu sârmă de bronz şi o paietă (PI. VI/1; PI. XI/13). Nu se precizează însă care a fost pozitiia lor în mormânt.

Tot din mormânt au mai fost recuperate o jumătate de sferă de fier, cu o perforaţie dreptunghiulară $\left(\mathbf{P I}\right.$. VIII/1) ${ }^{18}$ şi un fragment de piesă de fier $(\mathbf{P I} \text {. VIII/2) })^{19}$. Așa-zisele bile de fier, nu există. Poate doar aceste fragmente de fier, recuperate cu pământ pe ele să fi fost confundare cu niște bile. Este adevărat însă că am găsit două „bile” dar care au fost din pământ şi care la spălare s-au dezintegrat şi câteva pietricele. Lor li se mai adaugă un fragment de tub de fier (PI. VIII/3), dar care are cu totul alte dimensiuni decât cele indicate ${ }^{20}$ şi câteva bucățele de piele, cel mai probabil de vită (PI. VII/1-5).

Ambele morminte au avut aceeași poziție a defunctului. De asemenea, ambele au fost îngropate lângă monumente de cult din piatră, cu altarul semicircular.

Piesele de inventar, în bună parte de tradiție bizantină sau balcanică, descoperite în necropola de la Petrovcsics sugerează o datare pentru veacul al XIII-lea, eventual începutul secolului al XIV-lea.

La ambele morminte bogăția inventarului este aproape atipică pentru Ungaria secolelor XIIIXIV, exceptând mediul ortodox de influență bizantină observat în special spre periferia graniței sudice a Ungariei medievale (Cuptoare-Sfogea, Arača, Ilidia-Oblița). Prezența centurii cu aplice în morminte este oricum o raritate după secolul al X-lea. Obiceiul depunerii sale în complexele funerare reapare în special la venirea cumanilor ${ }^{21}$ în aceste regiuni. Interesant este însă faptul că aceste piese din mormintele atribuite cumanilor sunt în bună parte și de tradiție central europeană. În spaţiul Balcanic ea a fost în uz în diverse forme şi variante ${ }^{22}$.

\section{ANALIZA ANROPOLOGIC $\check{A}$}

Din scheletul descoperit în acest mormânt s-au mai recuperat doar câteva oase păstrate la Muzeul Național de Istorie a României, împreună cu fragmente de piese din inventarul său. Din coloana vertebrală s-au găsit doar trei vertebre lombare (PI. XII/1). Ele au dimensiuni reduse și evidențiază gracilitatea accentuată a individului respectiv. Este foarte posibil ca acest schelet să fi aparținut unei femei și să fi avut statura mică. Împreună cu oasele amintite, au mai fost găsite două oase metacarpiene $\left(\mathbf{P I}\right.$. XII/3b-c) și o falangă de la mâna stângă $\left(\mathbf{P I}\right.$. XII/1) ${ }^{23}$.

\section{ASPECTE PATOLOGICE}

Pe toate corpurile vertebrale se puteau observa tasări. De asemenea, apar corpusculi Schmorl, de diferite dimensiuni și adâncimi (PI. XII/3). În ordinea în care apar în fotografie, primul dintre ei este puțin adânc și are dimensiunile de $9,65 \times 8,68 \mathrm{~mm}$. Următorul măsoară $6,76 \times 5,37 \mathrm{~mm}$. Cei doi corpusculi găsiți pe ultima vertebră au dimensiunile de $6,43 \times 4,08 \mathrm{~mm}$, acesta fiind mai puțin adânc, respectiv de $8,03 \times 4,25 \mathrm{~mm}$, ultimul fiind mai adânc și mai îngust. Astfel de formațiuni apar ca o consecință a herniei intervertebrale a discurilor, care prezintă câteva forme de manifestare. Cea de care

\footnotetext{
${ }^{17}$ Stanojev 1989, 91-92, 94/fig. 502.

${ }^{18}$ Diametrul $=16 \mathrm{~mm}$; Înălțimea $=11 \mathrm{~mm}$.

${ }^{19}$ Lungime $=17 \mathrm{~mm}$; lățime $=17 \mathrm{~mm}$; Înălțime $=8 \mathrm{~mm}$.

${ }^{20}$ Real este: Diametrul $=14 \mathrm{~mm}$; Lungime $=38 \mathrm{~mm}$.

${ }^{21}$ Brmbolić 1996, 274-277.

${ }^{22}$ Rosetti 1972, 3, 6, fig. 4-10, p. 7, fig. 11-15; Alexandrov 1984, 34-36; Dumitriu 2001, Taf. 34, Taf. 35/1-19, Taf. 43, taf. 44, Taf. 45/1-13, 16, 17, Taf. 46; Doncheva 2012, 82-98; Reabțeva 2014, 127-146.

${ }^{23}$ Ifrim et alii 1983, 81; Traian 1993, 39.
} 
suntem interesați noi aici este cea numită hernie verticală a discului. Ea constă în îngustarea spațiului intervertebral, din cauza deformării discului cartilaginos situat între două vertebre, astfel încât acesta penetrează în spațiul trabecular al corpului vertebral. Etiologia specifică acestor corpusculi nu este bine definită dar, se pare ca un factor major care contribuie la formarea lor este procesul traumatic, care are drept consecință infecțiile, osteoporoza și boala neoplazică. Aceste probleme fac osul mult mai sensibil și facilitează proliferarea corpusculilor Schmorl ${ }^{24}$. O altă consecință a acestor formațiuni este degenerarea corpului vertebral. Se pare ca ele pot apărea și ca urmare a implicării coloanei vertebrale în eforturi prelungite, prin cărarea frecventă a greutăţilor în diferite moduri, sau prin ridicarea lor. Astfel de activități rezultă în apariția stresului biomecanic exercitat asupra coloanei vertebrale $^{25}$. Pe toate cele trei vertebre se pot observa și urme de osteoporoză.

\section{ASPECTE TAFONOMICE}

Toate oasele au o culoare verzuie, determinată de contactul cu un obiect din cupru sau bronz, care a fost puternic oxidat.

\section{BIBLIOGRAFIE}

Alexandrov 1984

Brmbolić 1996

Doncheva 2012

DIR

Dumitriu 2001

Györffy 1963

Heitel 2010

Ifrim et alii 1983

Jovanović 1977

Krznar 2015

Pletnjov, Pavlova 1994-1995

Reabţeva 2014

Roberts, Manchester 1995

Rosetti 1972

Stanojev 1989

Traian 1993
G. Alexandrov, Srednovekovno bălgarsko săkrovište ot Mihailovgrad, A Arheologija Sofia, 26, 1, 1984, p. 29-38

M. Brmbolić, The Kuman Belt from the Area of Tomaševac, Starinar, NS, XLVII, 1996, p. 273-277

S. Doncheva, A Silver Gilded Belt from the $13^{\text {th }}-14^{\text {th }}$ century, în $S$. Doncheva, Metal Art Production in Medieval Bulgaria. Jewelry craftsmanship in Bulgaria at the Middle Age, LAP, 2012, p. 82-98

Documente Privind Istoria României, C. Transilvania, București

L. Dumitriu, Der Mittelalterliche Schmuck des Unteren Donaugebietes im 11.-15. Jahrhundert, Bucharest, 2001

Gy. Györffy, Az Árpád-kori Magyarország Történeti Földrajza, I, Budapesta, 1963

S. M. Heitel, Inceputurile artei medievale în bazinul inferior al Mureșului, Timișoara, 2010

M. Ifrim et alii, Atlas de anatomie umană, I, Extremitatea cefalică, Trunchiul, Membrul superior, Membrul inferior, București, 1983

V. S. Jovanović, Prilozi hronologiji srednjevekovnih nekropola Jugoslavije i Bugarske. I, Balkanoslavica, Balcanoslavica, Institut za Staroslovenska Kultura, Prilep ,VI, 1977, p. 141-187

S. Krznar, Nova sezona istraživanja lokaliteta Torčec - Cirkvišče, Godišnjak Instituta za Arheologiju, Zagreb, XI, 2015, p. 54-58

V. Pletnjov, V. Pavlova, Rannosrednovekovni remăčni aplikacii văv Varnenskija arheologičeski muzej, Izvestija na Narodnija Muzej, Varna, 3031 (45-46), 1994-1995, p. 24-239

S. Reabţeva, Piese de podoabă şi vestimentaţie din Moldova şi Ţara Românească în contextul relațiilor cultural istorice (secolele XIV-XVII), Brăila, 2014

Ch. Roberts, Manchester, K., The Archaeology of Disease, Cornell Publishing Limited, Cornell University Press, Ithaca, New York, 1995

D. V. Rosetti, Tezaurul de podoabe medievale de la Olteni (Teleorman) şi elementele lor bizantine, Buletinul Monumentelor Istorice, Institutul Național al Patrimoniului, București, XLI, 4, 1972, p. 3-14

N. Stanojev, Nekropole $X-X V$ veka u Vojvodini. 712 Kataloških jedivica, Novi Sad, 1989

T. Traian, Atlas de anatomie umană. Osteologie, Fascicula 1, București, 1993

\footnotetext{
${ }^{24}$ Roberts, Manchester 1995, 107.

${ }^{25}$ Stirland, Waldron 1997, 329-335.
} 
Stirland, Waldron 1997

Suciu 1968

Whitehead 1996
A. J. Stirland, T. Waldron, Evidence for Activity Related Markers in the Vertebrae of the Crew Mary Rose, Journal of Archaeological Science, 24 (1997), p. 329-335

C. Suciu, Dicționar istoric al localităților din Transilvania, II, București, 1968

R. Whitehead, Buckles. 1250 - 1800, Essex, 1996

\section{LISTA ILUSTRAȚIEI}

PI. I. Harta descoperirilor.

PI. II. 1. Aplice de centură (fragmente); 2. Aplice de centură rectangulare; 3. Aplice de centură; 4. Aplice tip floare (fragmente); 5. Centură; 6. Aplice tip floare (fragmente).

Pl. III. 1, 8. Aplice de centură (sparte); 2-6, 9-15. Aplice tip floare (fragmente); 7. Nit; 16-19. Aplice alungite (fragmente); 20-21. Aplice triunghiulare (fragmente).

PI. IV. 1. Nituri; 2. Aplice tip floare (fragmente).

Pl. V. 1. Nituri şi aplice (fragmente); 2, 3, 5, 7, 12, 15. Aplice tip floare (fragmente); 4, 8, 9, 13, 14. Aplice alungite (fragmente); 6, 10, 11, 16-19. Nituri; 20. Nituri, piele și aplice (fragmente).

PI. VI. 1. Sfoară împletită și paietă; 2, 2a, 9. Nituri; 3, 3a, 4, 4a, 5, 5a, 6, 6a, 7, 7a, 8, 8a, 9. Aplice alungite (fragmente); 10. Aplice tip floare (fragmente).

PI. VII. 1-5. Centură de piele (fragmente); 6-7. Pietre mici.

PI. VIII. 1-2. Centură de piele (fragmente); 3. Tub de fier (fragment); 4, 4a, 5, 5a, 6, 6a, 7, 7a, 8, 8a. Cuie (fragmente).

PI. IX. Aplice de centură. 1. Fotografie; 2. Radiografie.

PI. X. Reconstituire parțială.

PI. XI. 1. Cataramă; 2-4. Aplice tip floare; 5a-b, 6. Aplice tip floare (fragmente); 7. Aplice alungite (fragmente); 8. Nituri; 9. Aplică; 10. Aplică; 11. Aplică de centură; 12a-c. Sfoară împletită; 13. Paietă.

Pl. XII. 1. Vertebre lombare ale individului descoperit în mormântul nr. 1; 2.1. Falanga; 2-3. Oase metacarpiene; 3. Corpisci Schmorl pe corpurile vertebrale.

\section{LIST OF ILLUSTRATIONS}

PI. I. The localisation of the sites.

PI. II. 1. Belt appliqués (fragments); 2. Rectangular belt appliqués; 3. Belt strap; 4. Flower type appliqués (fragments); 5. Belt; 6. Flower type appliqués (fragments).

Pl. III. 1, 8. Belt appliqué (broken); 2-6, 9-15. Flower type appliqués (fragments); 7. Rivet; 16-19. Elongated appliqués (fragments); 20-21. Triangular appliqués (fragments).

Pl. IV. 1. Rivets; 2. Flower type appliqués (fragments).

Pl. V. 1. Rivets and appliqués (fragments); 2, 3, 5, 7, 12, 15. Flower type appliqués (fragments); 4, 8, 9, $13,14$. Elongated appliqués (fragments); 6, 10, 11, 16-19. Rivets; 20. Rivets, leather and appliqués (fragments).

PI. VI. 1. Rope braids and spangle; 2, 2a, 9. Rivets; 3, 3a, 4, 4a, 5, 5a, 6, 6a, 7, 7a, 8, 8a, 9. Elongated appliqués (fragments); 10. Flower type appliqués (fragments).

PI. VII. 1-5. Leather belt (fragments); 6-7. Small stones.

Pl. VIII. 1-2. Leather belt (fragments); 3. Iron tube (fragment); 4, 4a, 5, 5a, 6, 6a, 7, 7a, 8, 8a. Nails (fragments).

PI. IX. Belt strap. 1. Photo; 2. Radiography.

PI. X. Partial reconstitution.

PI. XI. 1. Buckle; 2-4. Flower type appliqués; 5a-b, 6. Flower type appliqués (fragments); 7. Elongated appliqués (fragments); 8. Rivets; 9. Appliqué; 10. Appliqué; 11. Belt strap; 12a-c. Rope braids; 13. Spangle.

PI. XII. 1. Dorsal vertebrae of the individual discovered in Grave no. 1; 2.1. Phalanx; 2-3. Metacarpal bones; 3. Schmorl's nodes on the vertebral bodies.

SILVIU OȚA,

Muzeul National de Istorie al României silviuota@yahoo.com ALEXANDRA COMŞA Institutul de Arheologie „Vasile Pârvan”, București alexconsa63@yahoo.com 


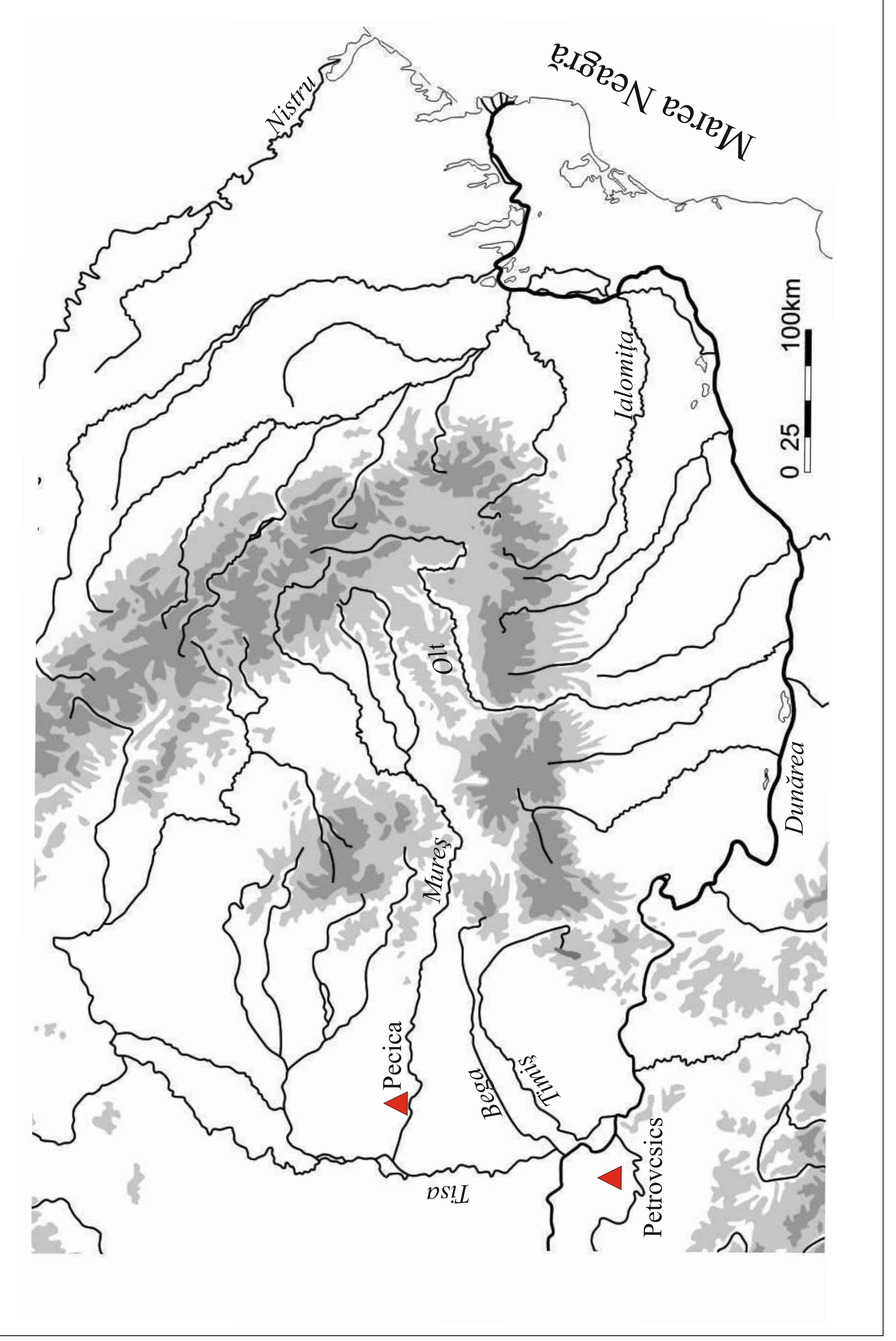




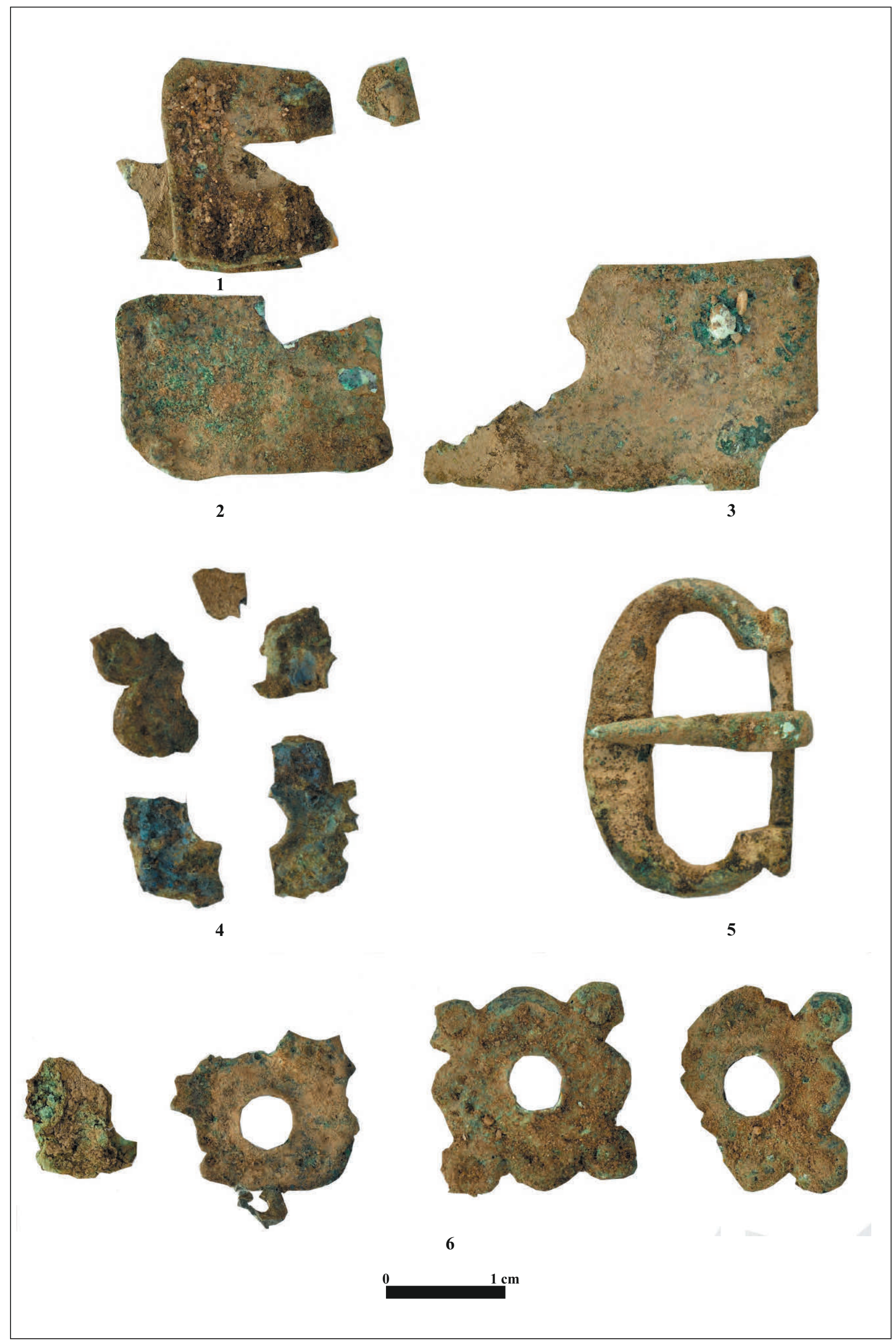

PI. II 


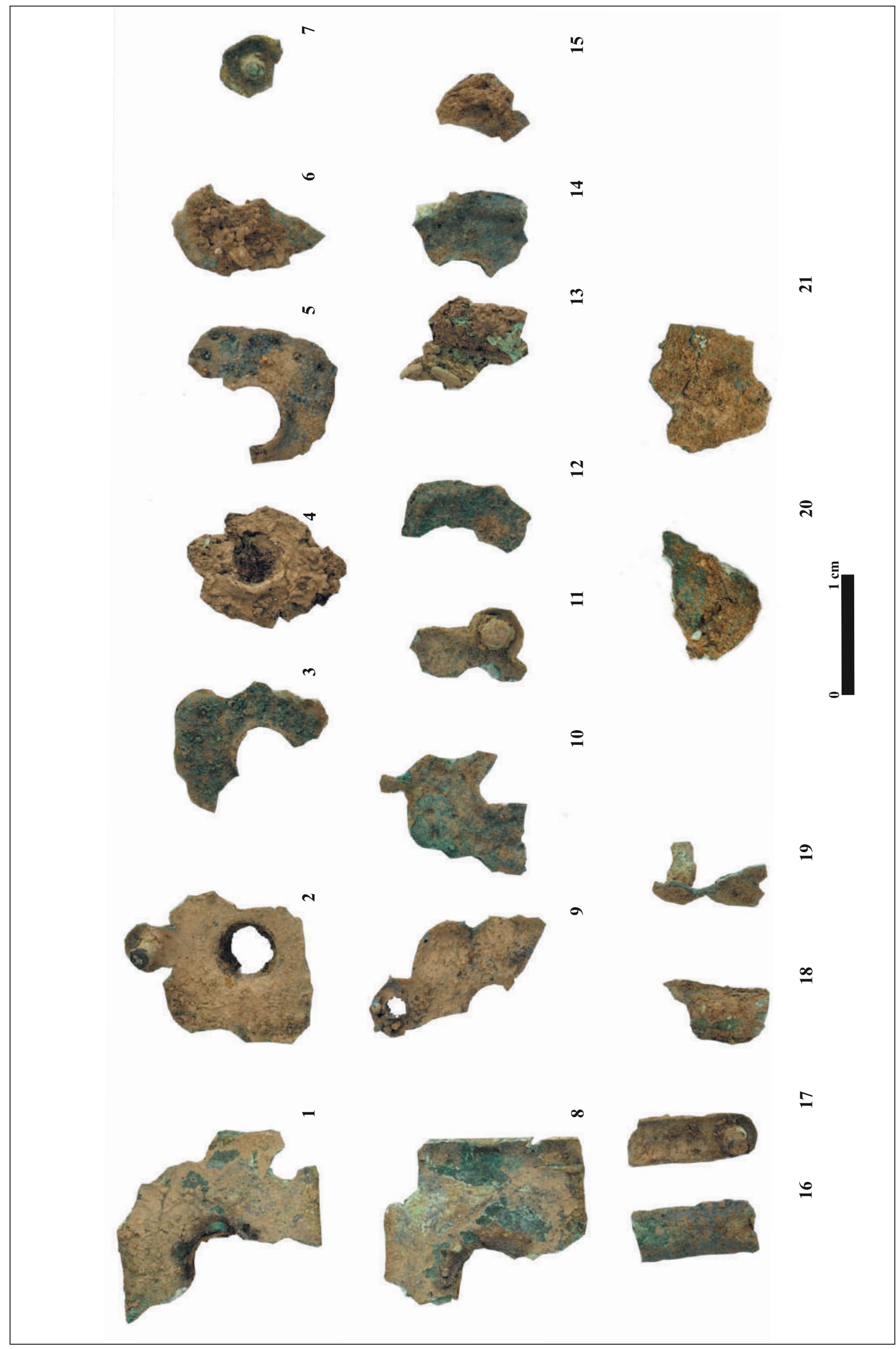




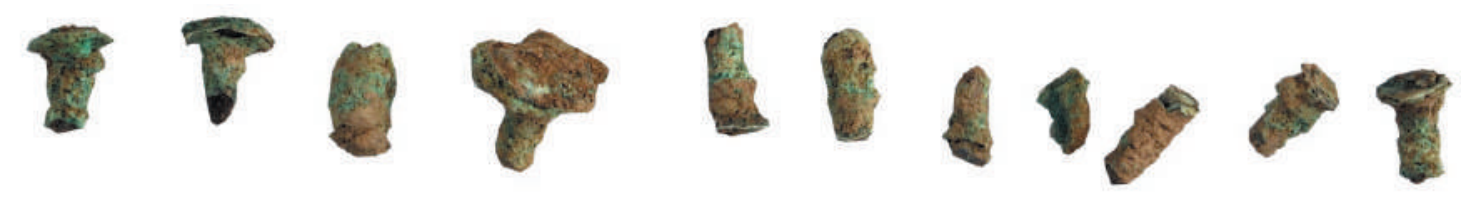 ⿰亻⿱ T TRT H T \\ 1111 ह
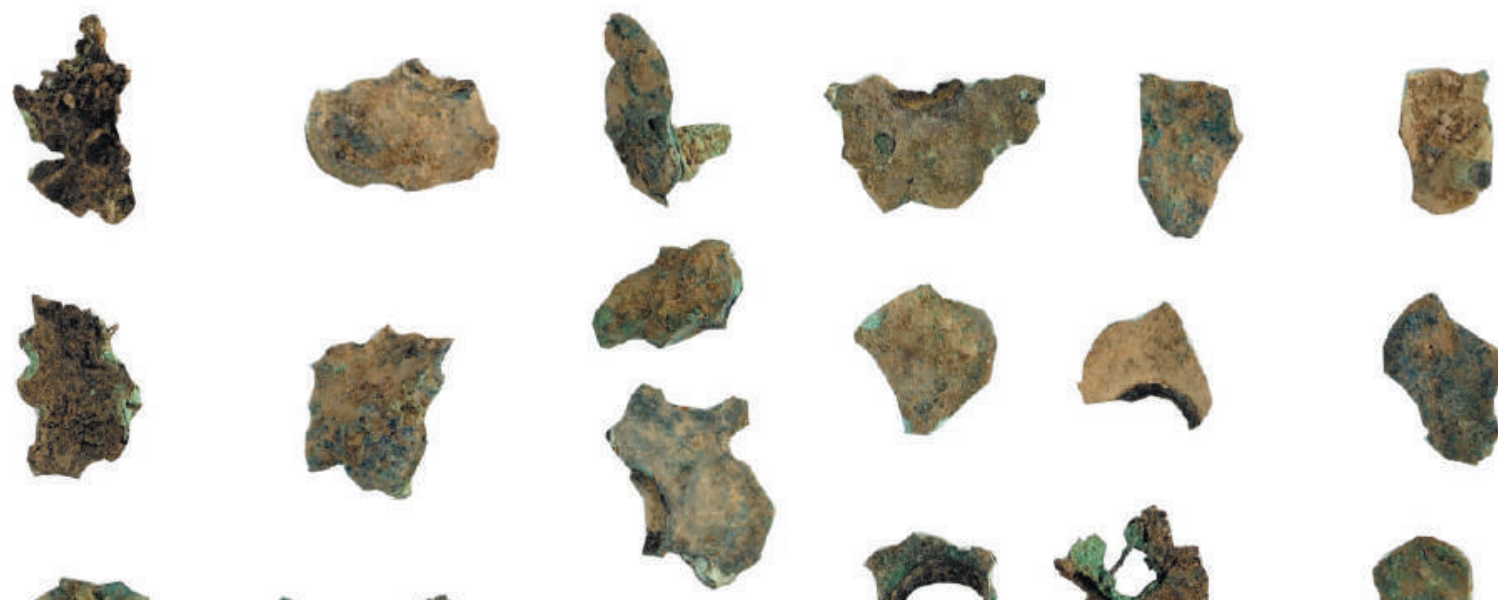

12
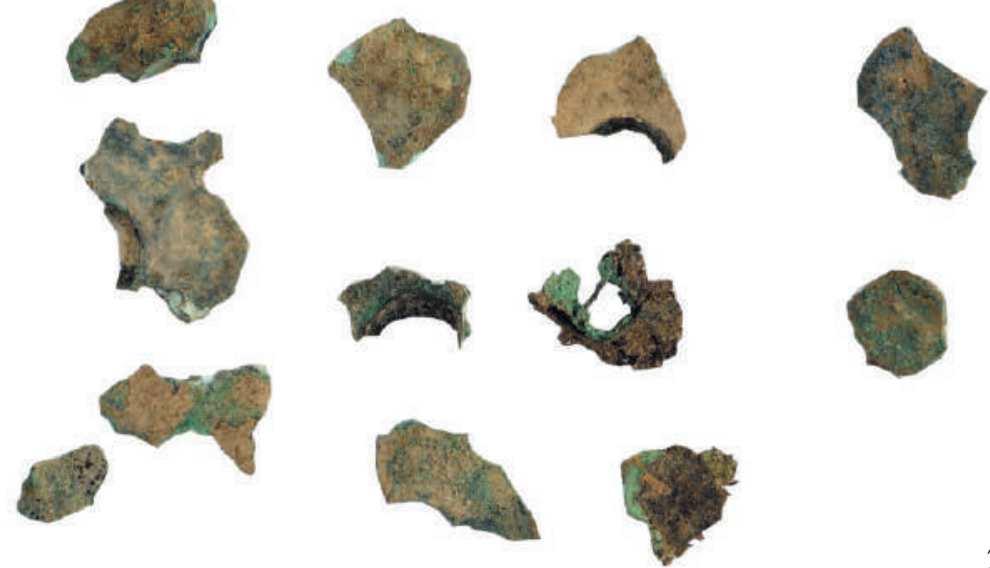


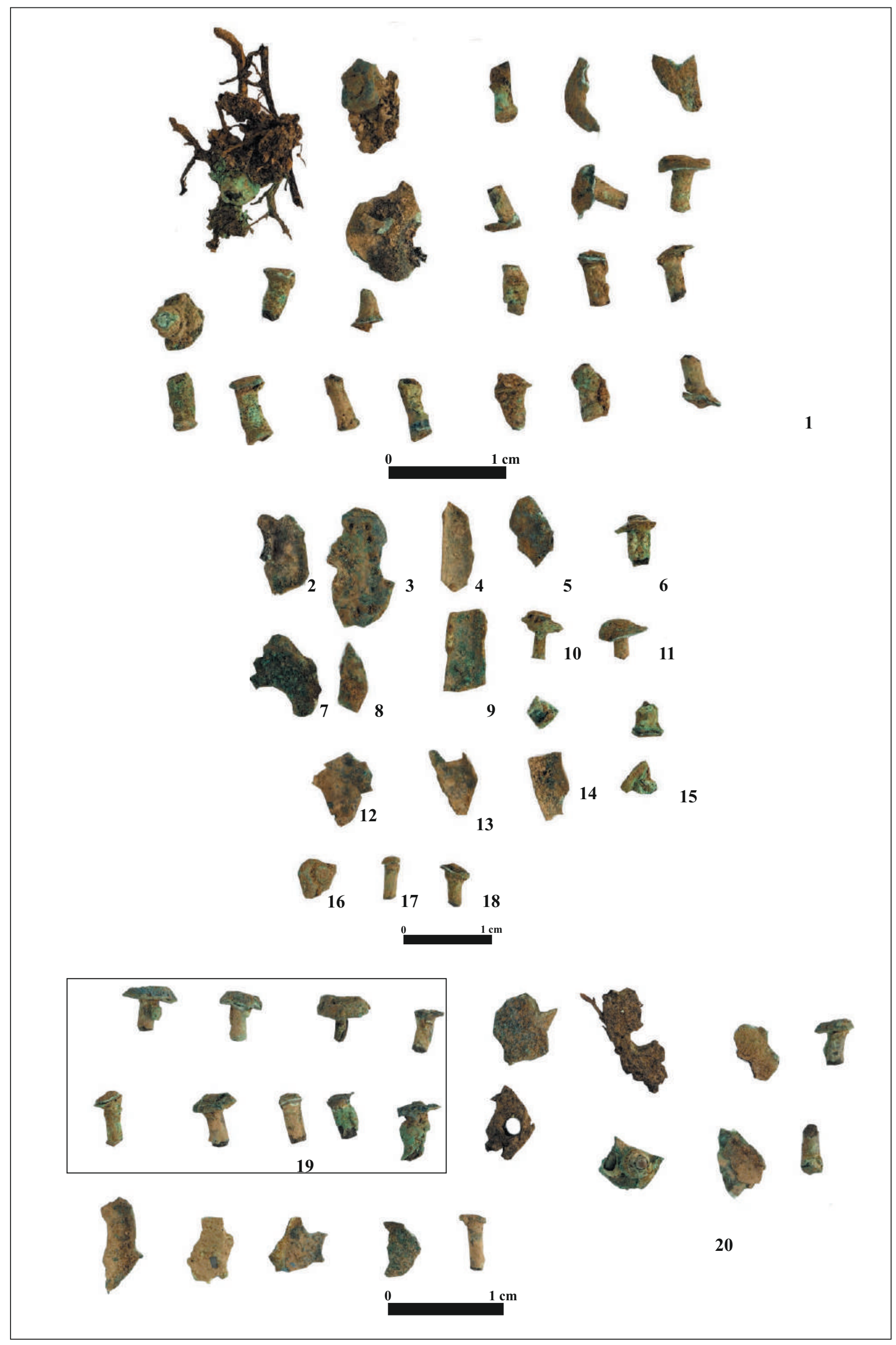

PI. V 


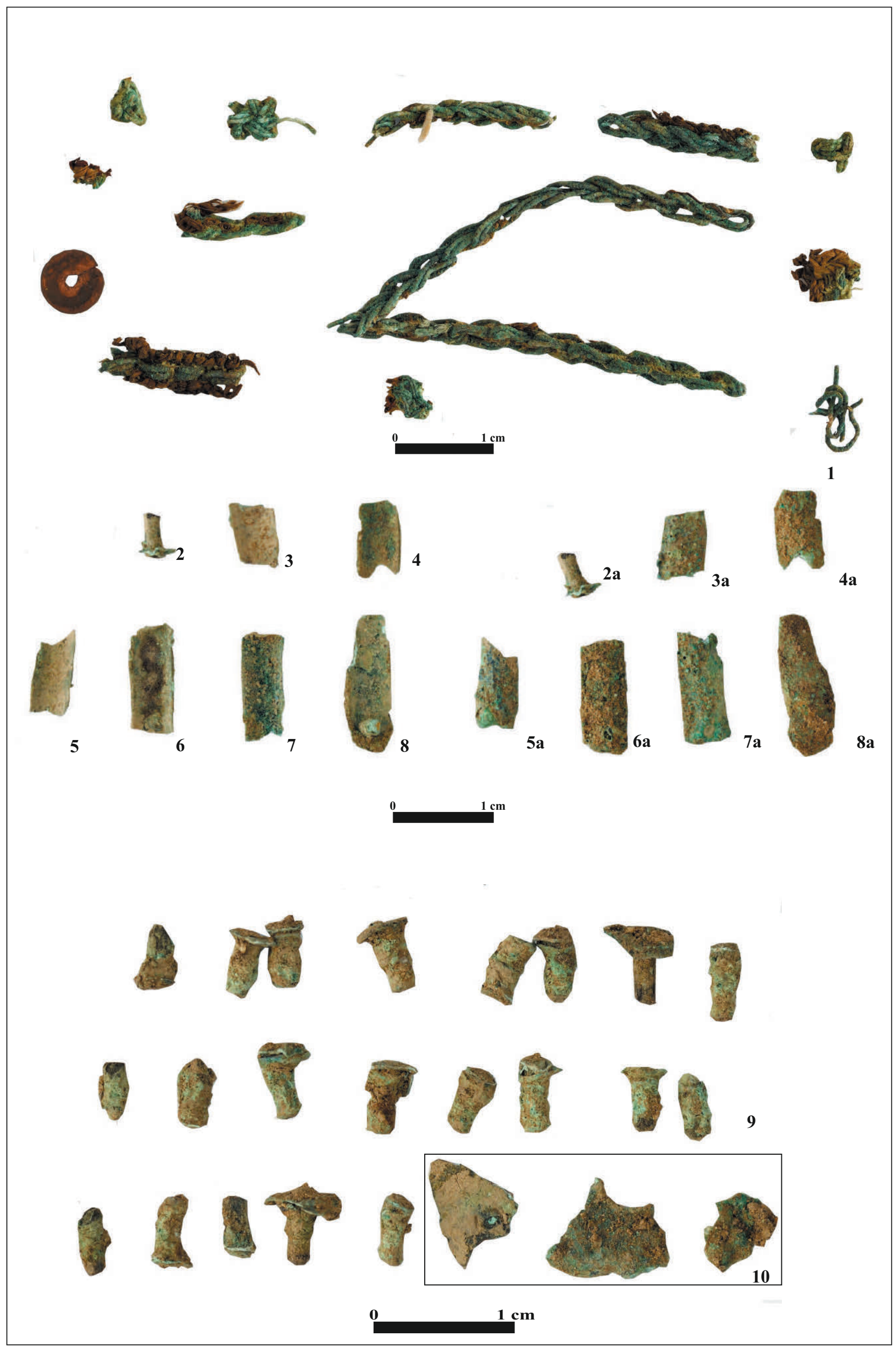

PI. VI 


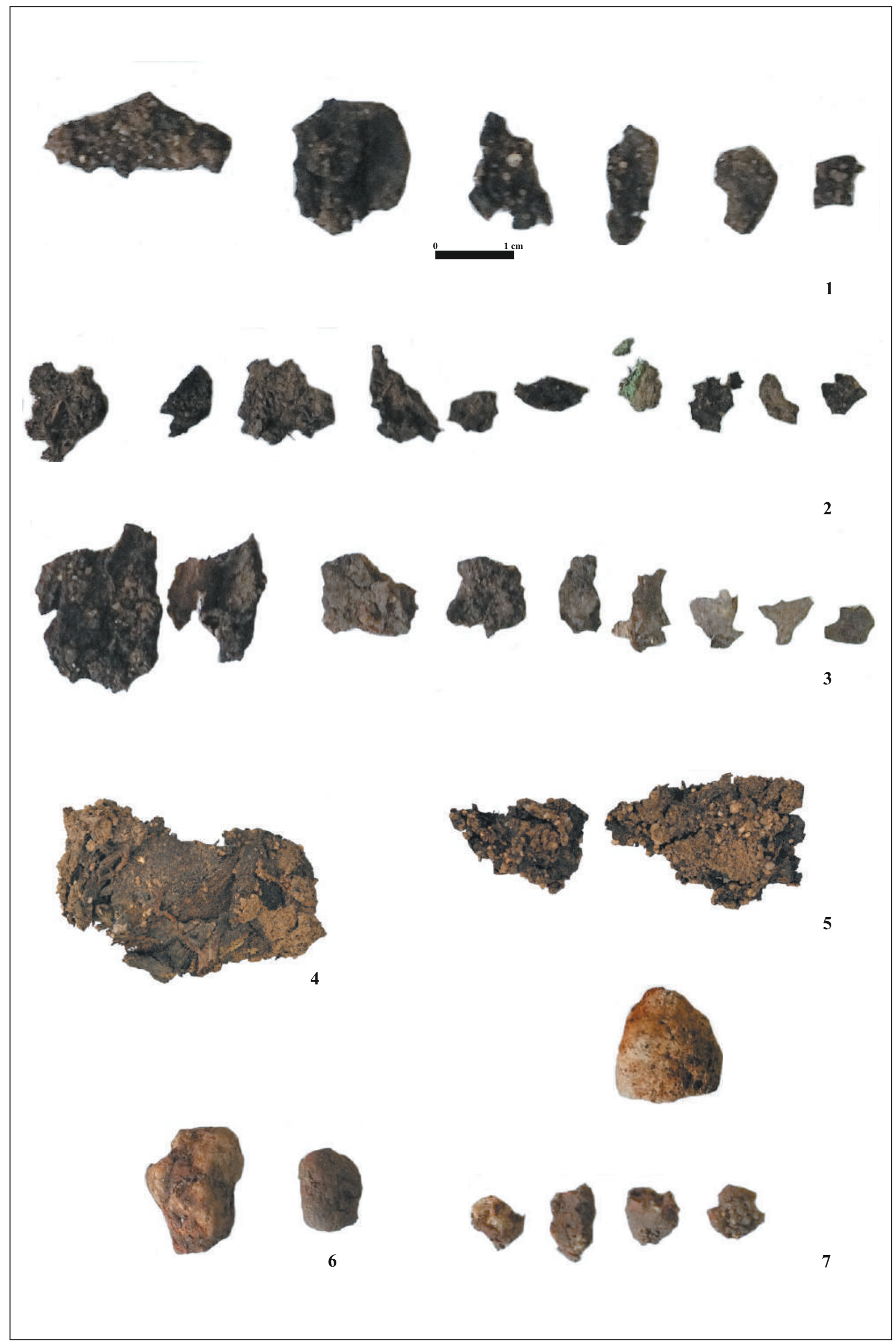

PI. VII 

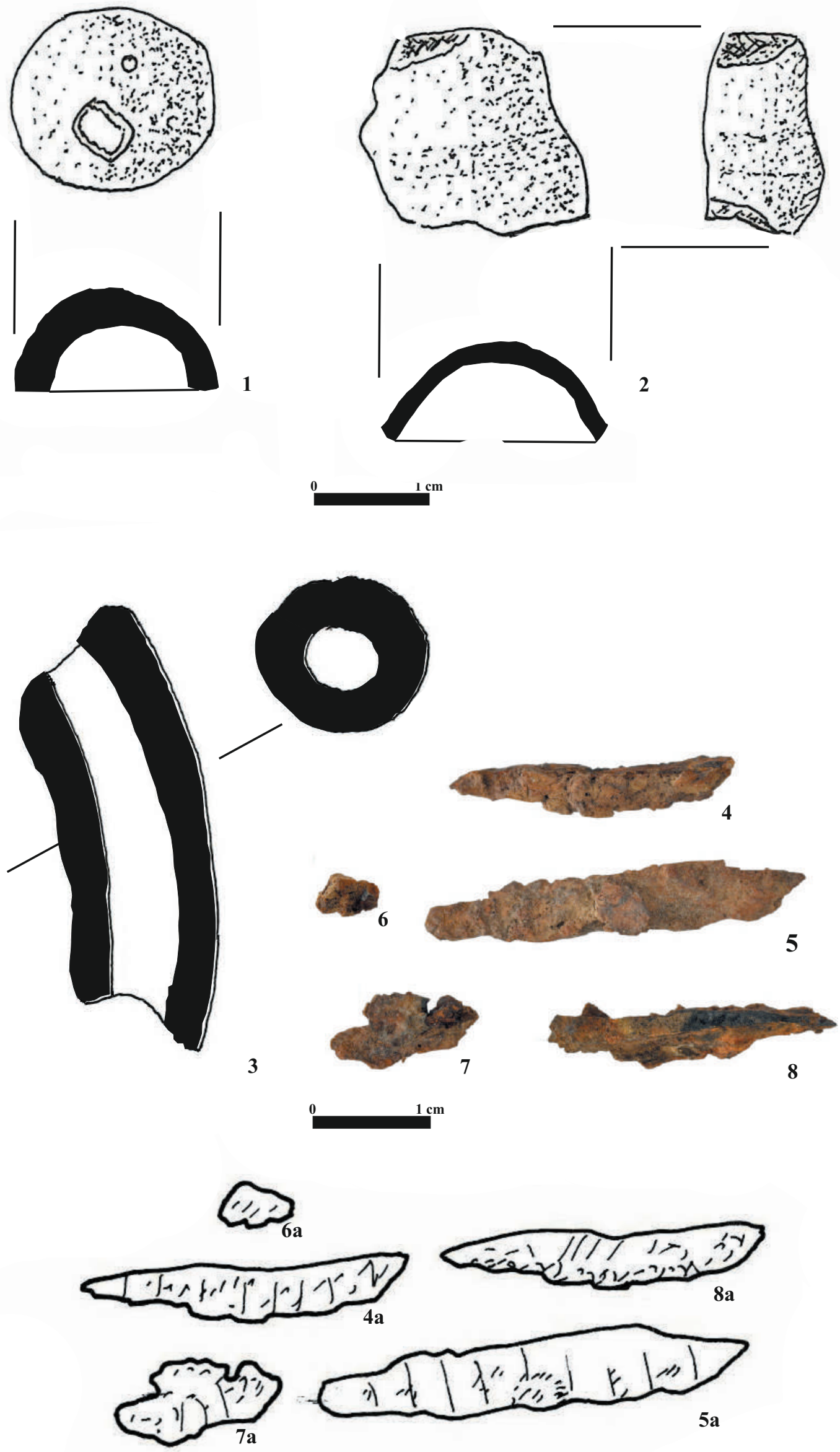


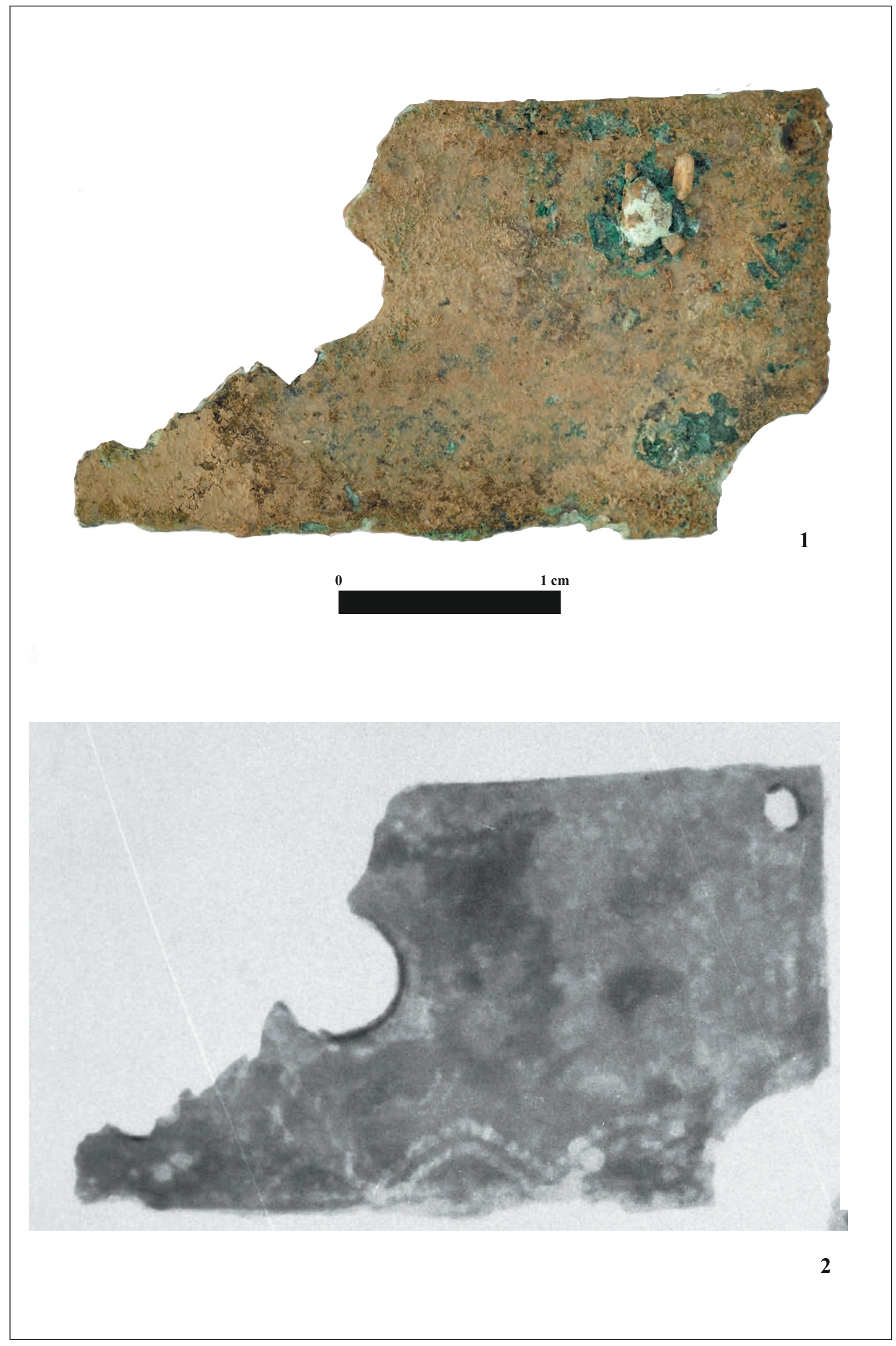

PI. IX 


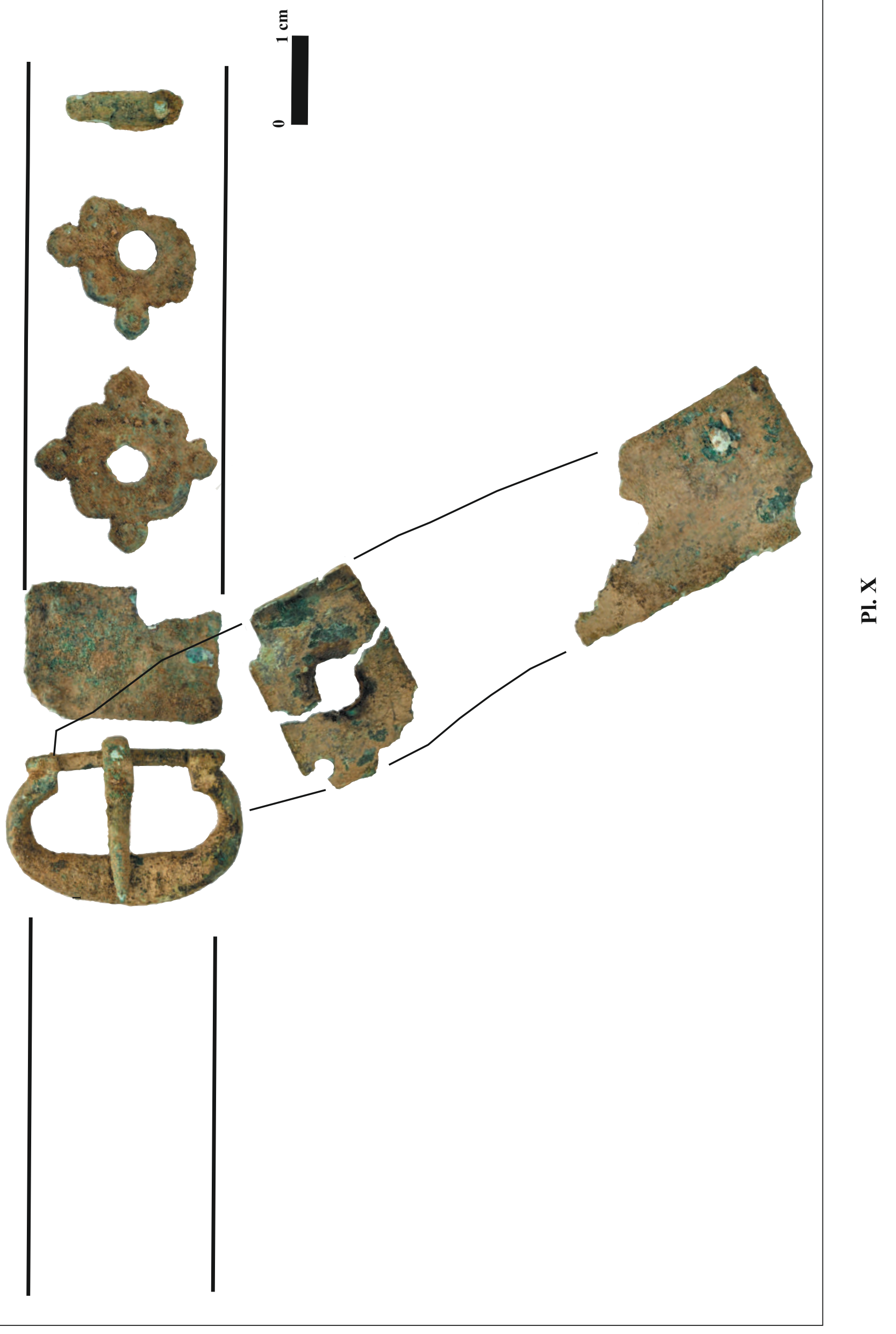



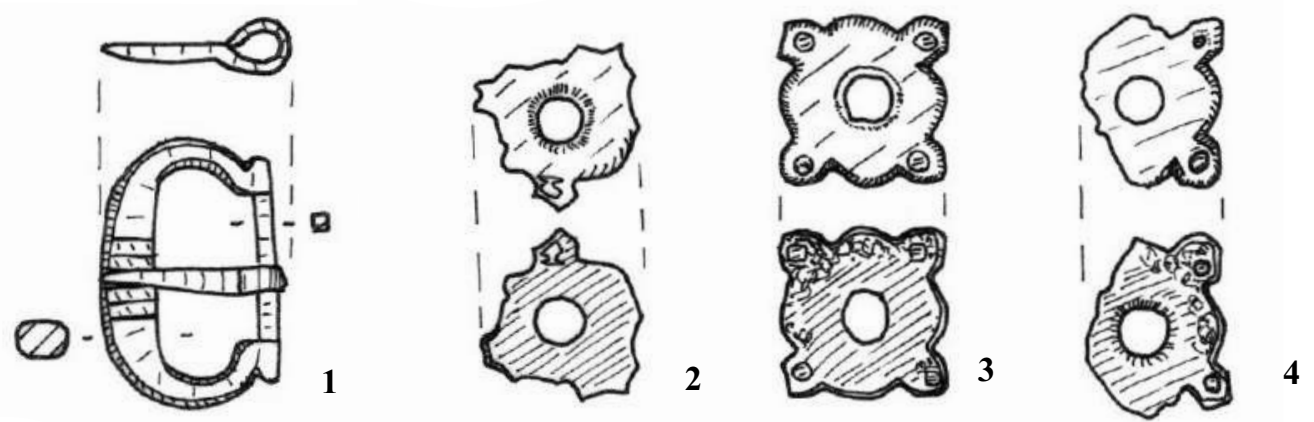

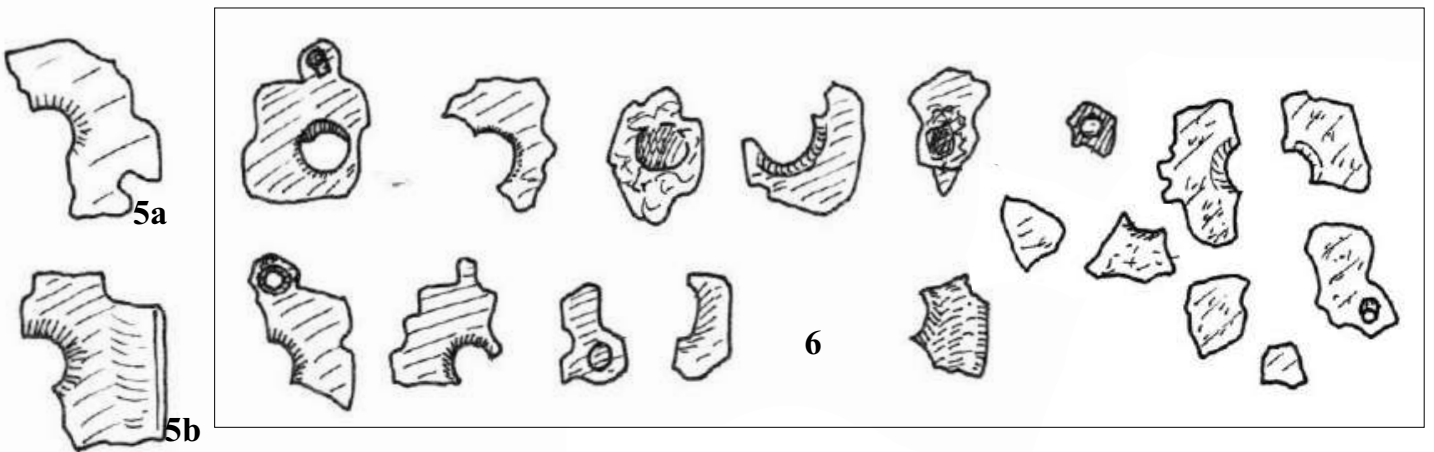

算鼻自架

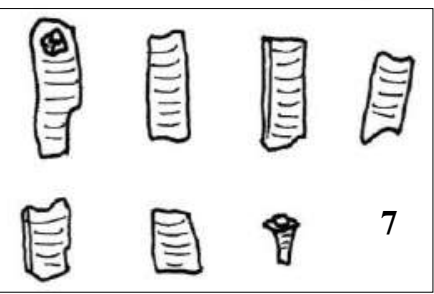

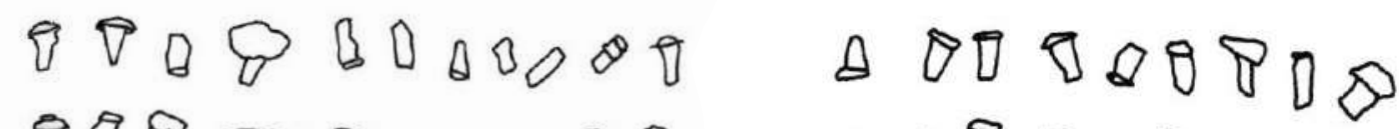

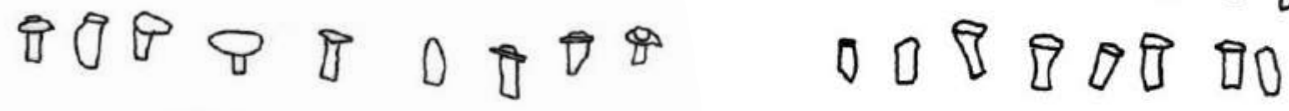

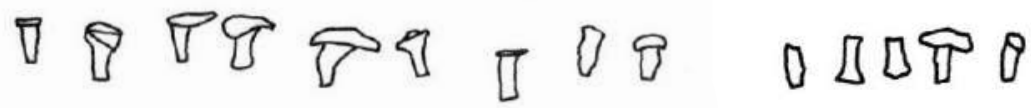
Q DQ UDQ
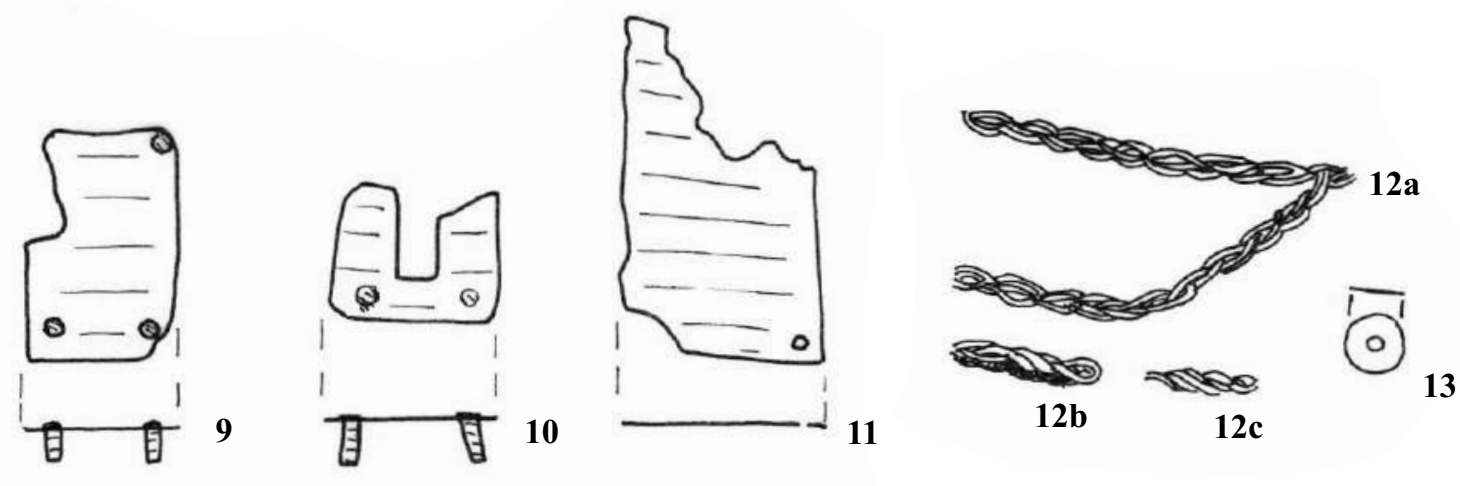


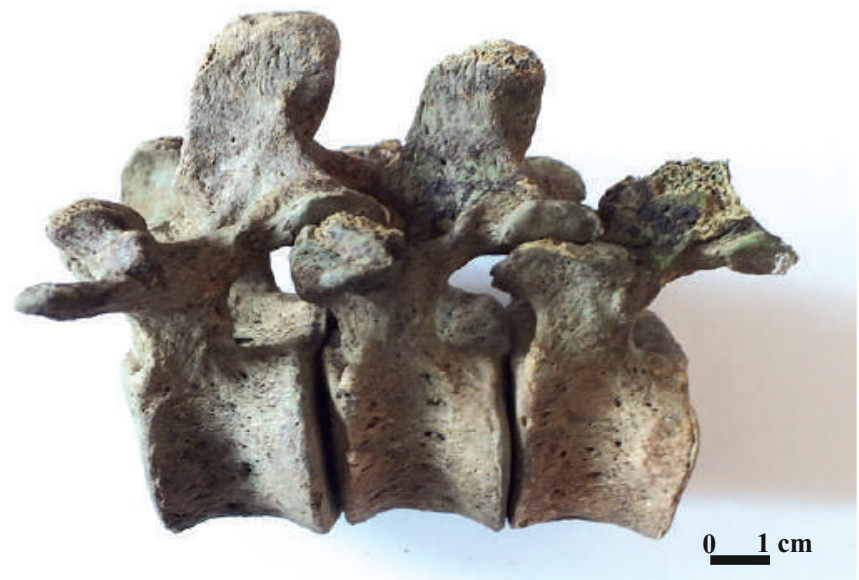

1
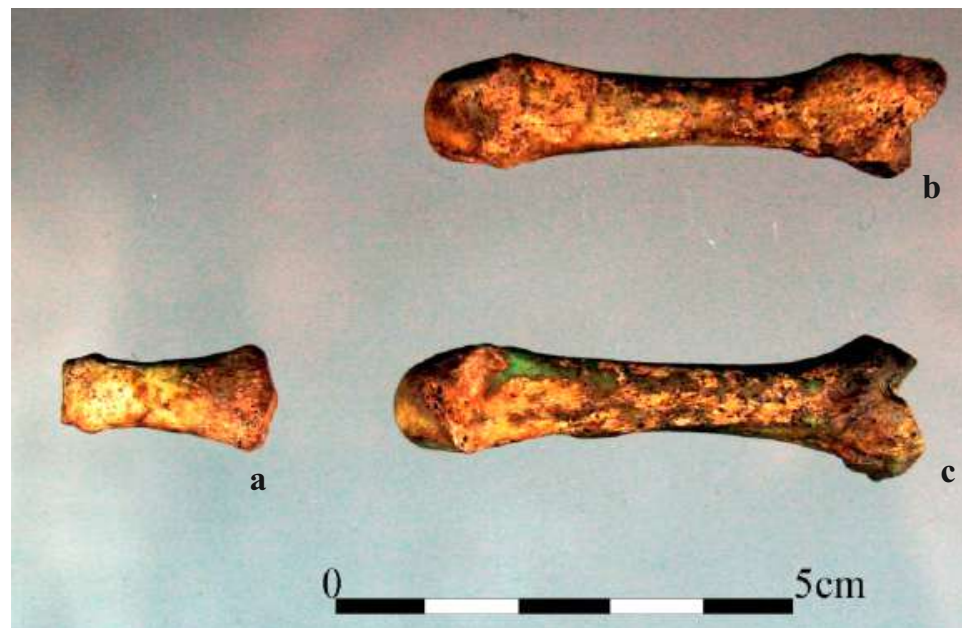

2

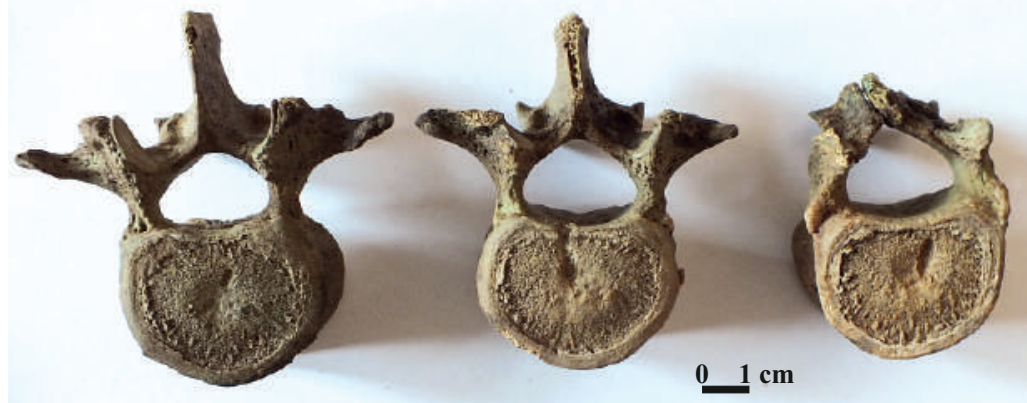

PI. XII 